\title{
Continental-scale variability in the feeding ecology of juvenile Chinook salmon along the coastal Northeast Pacific Ocean
}

\author{
Eric Hertz ${ }^{1, *}$, M. Trudel ${ }^{1,2}$, R. D. Brodeur ${ }^{3}$, E. A. Daly ${ }^{4, * *}$, L. Eisner ${ }^{5, * *}$, \\ E. V. Farley Jr. ${ }^{5, * *}$, J. A. Harding ${ }^{6, * *}$, R. B. MacFarlane ${ }^{6, * *}$, S. Mazumder ${ }^{1, * *}$, \\ J. H. Moss ${ }^{5, * *}$, J. M. Murphy ${ }^{5, * *}$, A. Mazumder ${ }^{1}$
}

\footnotetext{
${ }^{1}$ Department of Biology, University of Victoria, PO Box 3020, Station CSC, Victoria, British Columbia V8W 3N5, Canada

${ }^{2}$ Pacific Biological Station, Fisheries and Oceans Canada, 3190 Hammond Bay Road, Nanaimo, British Columbia V9T 6N7, Canada

${ }^{3}$ National Marine Fisheries Service, Northwest Fisheries Science Center, Hatfield Marine Science Center, 2030 S. Marine Science Drive, Newport, Oregon 97365, USA

${ }^{4}$ Cooperative Institute for Marine Resources Studies, Oregon State University, Hatfield Marine Science Center, 2030 S. Marine Science Drive, Newport, Oregon 97365, USA

${ }^{5}$ National Marine Fisheries Service, Alaska Fisheries Science Center, Auke Bay Laboratories,

Ted Stevens Marine Research Institute, 17109 Point Lena Loop Road, Juneau, Alaska 99801-8626, USA

${ }^{6}$ National Oceanic and Atmospheric Administration-Fisheries, Southwest Fisheries Science Center, Santa Cruz Laboratory, 110 Shaffer Road, Santa Cruz, California 95060, USA
}

\begin{abstract}
Trophic interactions within and among species vary widely across spatial scales and species' ontogeny. However, the drivers and implications of this variability are not well understood. Juvenile Chinook salmon Oncorhynchus tshawytscha have a wide distribution, ranging from northern California to the eastern Bering Sea in North America, but it is largely unknown how their feeding ecology varies and changes with ontogeny across this range. We collected juvenile Chinook salmon and zooplankton using standardized protocols along the coastal Northeast Pacific Ocean. Using a combination of stomach contents and stable isotopes of nitrogen $\left(\delta^{15} N\right)$ and carbon $\left(\delta^{13} \mathrm{C}\right)$ to characterize feeding ecology, we found regional differences in prey utilization by juvenile Chinook salmon. With growth and ontogeny, juvenile salmon in all regions became equilibrated with oceanic isotopic values. There were regional differences in the $\delta^{13} \mathrm{C}$ values of juvenile Chinook salmon that may correspond to regional differences in sea surface temperature. There were also regional differences in stable isotope-derived trophic level, and these estimates differed from those derived from stomach contents, possibly due to the different periods over which these metrics integrate. Dietary niche width, as indicated by stable isotopes, corresponded to the expected dietary diversity from stomach contents, combined with the isotopic variability seen in baseline values. Our results indicate strong geographic and ontogenetic differences in feeding ecology of juvenile Chinook salmon. These differences are likely influenced by a combination of ocean-entry date, ocean-entry size, ontogeny, growth rates and regional conditions.
\end{abstract}

KEY WORDS: Diet - Stable isotope - Trophic level - Turnover - Diet dependent discrimination factor · Oncorhynchus tshawytscha $\cdot$ Carbon $\cdot$ Nitrogen $\cdot$ Niche width $\cdot$ Ontogeny

Resale or republication not permitted without written consent of the publisher

\section{INTRODUCTION}

Understanding trophic interactions within and among species is a central theme in ecology, and is increasingly important as fisheries science moves towards ecosystem based management (Larkin 1996,
Pikitch et al. 2004). Due to the complexity of modeling entire ecosystems, current approaches generally assume that trophic interactions are static, often ignoring significant spatial and temporal variability in trophic dynamics. For example, the same species can have divergent niches in different habitats 
(McCann et al. 2005), but the causes and consequences of these niche differences are largely unknown.

Further complicating the study of trophic interactions are the ontogenetic shifts in feeding ecology common in many species (Werner \& Gilliam 1984). These ontogenetic niche shifts may have widespread effects on population and community dynamics (de Roos \& Persson 2013), such as promoting the coexistence of competitors (Wollrab et al. 2013), reducing the stabilizing effects of ecosystem complexity (Rudolf \& Lafferty 2011), and even altering the strength of trophic cascades (Rudolf \& Rasmussen 2013). Variations in trophic interactions as a result of ontogenetic niche shifts are beginning to be considered in experimental and modeling food web studies (van Leeuwen et al. 2014), but there are few empirical examples of variation in species ontogeny in field settings across large geographic scales.

Ontogenetic niche shifts are prevalent in fish, especially those that are piscivorous. Juvenile fish may be gape limited, and thus must feed on small prey items at small sizes (Nunn et al. 2012). With growth, maximum and minimum prey sizes generally increase, though the rate of change of these relationships may be modulated by species and habitat (Scharf et al. 2000, Keeley \& Grant 2001). These ontogenetic shifts to larger prey items may be important because growth efficiency is higher and metabolic costs are lower when feeding on larger prey (Pazzia et al. 2002), and fish prey are generally higher in caloric value (Davis et al. 1998).

Stomach content analysis and stable isotope analysis (SIA) are 2 common methods used to track ontogenetic shifts, each with its own inherent limitations and assumptions. Stomach contents can give a great deal of taxonomic resolution in diet, but only represent a snapshot of diet in time, and can be biased by differences in the digestibility of prey items (Polunin \& Pinnegar 2002). Conversely, stable isotopes in the muscle tissue of an organism represent material assimilated over a period of weeks to months (Fry 2006). Stable isotopes of nitrogen $\left(\delta^{15} \mathrm{~N}\right)$ generally indicate trophic position, as $\delta^{15} \mathrm{~N}$ undergoes a trophic enrichment of approximately $3.4 \%$ per trophic level (Post 2002), although recent studies have indicated that the value of this trophic enrichment may decrease with increasing dietary $\delta^{15} \mathrm{~N}$ (Caut et al. 2009, Hussey et al. 2014). $\delta^{15} \mathrm{~N}$ values at the base of the food web are also variable, such that estimates of consumer trophic level are often calculated relative to a baseline primary consumer (Cabana \& Rasmussen 1996, Hussey et al. 2014). For stable isotopes of carbon $\left(\delta^{13} \mathrm{C}\right)$, there is a general onshore/offshore pattern in coastal waters, with onshore waters being enriched in $\delta^{13} \mathrm{C}$ by up to $5 \%$ (Perry et al. 1999, Miller et al. 2008). This pattern may be due to differences in the productivity of phytoplankton (Schell 2000, Miller et al. 2008) as the fractionation of $\delta^{13} \mathrm{C}$ in phytoplankton is related to species and growth rate, with higher $\delta^{13} \mathrm{C}$ values associated with larger cell sizes and greater growth rates (Laws et al. 1995). Temperature can also affect $\delta^{13} \mathrm{C}$ values, since the amount of dissolved $\mathrm{CO}_{2}$ in surface waters is inversely related to sea surface temperature (SST; Weiss 1974). These higher concentrations of dissolved $\mathrm{CO}_{2}$ lead to lower $\delta^{13} \mathrm{C}$ values at lower SSTs (McMahon et al. 2013). So, while stable isotopes can indicate trophic level $\left(\delta^{15} \mathrm{~N}\right)$ and source of production $\left(\delta^{13} \mathrm{C}\right)$, there is generally an overall lower taxonomic resolution than with stomach contents, and the assumptions must be made that there is a known trophic enrichment, and that the organism is at equilibrium with the isotopic baseline of the environment (Buchheister \& Latour 2010). Thus overall, a powerful method to trace diet and ontogeny would be to use both stomach contents and SIA.

Along the west coast of North America, juvenile Chinook salmon Oncorhynchus tshawytscha are generalist predators that feed on a variety of juvenile fish and invertebrate prey (Brodeur et al. 2007, Daly et al. 2009). Chinook salmon are anadromous, and upon ocean entry begin feeding on invertebrates before shifting to preying primarily on fish (Brodeur 1991). Since mortality for juvenile Chinook salmon may be size-selective in their early marine life (Claiborne et al. 2011, Duffy \& Beauchamp 2011, Woodson et al. 2013), the shift to feeding on higher-quality fish prey may be important for their overall survival rates.

Juvenile Chinook salmon show variation in diet at various spatial scales throughout their range (Brodeur et al. 2007, Davis et al. 2009, Duffy et al. 2010). In North America, the spawning range of Chinook salmon spans 3 oceanographic domains: the eastern Bering Sea shelf, the Alaska Coastal Current System, and the California Current System. In the eastern Bering Sea shelf, primary productivity and food web structure is related to ice cover (Hunt et al. 2002), with north-south and cross-shelf variations (Brown et al. 2011, Eisner et al. 2014), and a high abundance of fish prey in the pelagic zone (Farley et al. 2005). The Alaska Coastal Current is a downwelling system (Ware \& McFarlane 1989), with high prey quality (Lee et al. 2006) and a fish community composed largely of salmonids (Orsi et al. 2007). The California Current System is an upwelling system 
(Hickey 1979, Ware \& McFarlane 1989), with relatively lower prey quality (Lee et al. 2006) and higher biomass of other fish species relative to juvenile salmon (Orsi et al. 2007). Prey quantity varies on several spatial and temporal scales throughout this range, though on an annual basis the highest primary and secondary productivity occurs off the coast of Vancouver Island at the north end of the California Current System (Ware \& Thomson 2005, Hickey \& Banas 2008). Combined, these regional differences have been hypothesized to affect the feeding habits of juvenile Chinook salmon (Brodeur et al. 2007).

Independent of regional oceanography and community composition, size differences of juvenile salmon may also contribute to diet differences among regions. At ocean entry, juvenile Chinook salmon range in size from an average of $75 \mathrm{~mm}$ on the West Coast of Vancouver Island to $160 \mathrm{~mm}$ in Oregon and Washington (Trudel et al. 2007). As larger juvenile salmon generally tend to be more piscivorous (Brodeur 1991), this regional variation in size may have implications for diet. The diet shift that occurs with size also varies by region, with clear ontogenetic shifts to piscivory in Oregon and Washington (Brodeur 1991, Daly et al. 2009), but little evidence of ontogenetic shifts in southeast Alaska (Weitkamp \& Sturdevant, 2008). Of note, previous studies on the ontogeny of juvenile Chinook salmon have generally reported diet from only a single region or sampling program, and used only one metric of diet to observe ontogenetic niche shifts.

In this study, our main objective was to examine regional variability in the feeding ecology and ontogeny of juvenile Chinook salmon. To do so, we assembled the largest data set available on stable isotopes and stomach contents of salmon from northern California to the eastern Bering Sea. These data were collected during $1 \mathrm{yr}$ and 1 season to minimize temporal variability. First, to account for variability in ontogeny, size-selective feeding, and latitude, we determined how the $\delta^{13} \mathrm{C}, \delta^{15} \mathrm{~N}$, and stomach contents of juvenile salmon vary by region and body size. Because previous studies on the stomach contents of juvenile Chinook salmon have indicated that they are generally more piscivorous in the eastern Bering Sea, Southeast Alaska, and Oregon/Washington than in other regions (Brodeur et al. 2007), we hypothesized that these regions would be similarly higher in stable isotope-derived trophic levels. In contrast, because there is a general south to north decline in SST, we hypothesized that $\delta^{13} \mathrm{C}$ values would be highest in the southern regions, and become increasingly lower in the north. We concluded the study by combining both diet approaches to examine variation on a continental scale, and specifically, to determine whether there was concordance between long-term assimilated diet as indicated by stable isotopes, and the snapshot of recent diet as indicated by stomach contents.

\section{MATERIALS AND METHODS}

\section{Field sampling and laboratory analysis}

Samples were collected off the coasts of California (CA), Oregon and Washington (ORWA), the west coast of Vancouver Island in British Columbia (WCVI), central British Columbia (CEBC), southeast Alaska (SEAK), southeastern Bering Sea (SEBS), and the northeastern Bering Sea (NEBS) (Fig. 1). NEBS and SEBS were separated along the $60^{\circ} \mathrm{N}$ latitude line, based on the distribution and migration routes of juvenile salmon (Farley et al. 2009). In NEBS and SEBS, we retained juveniles that were less than $325 \mathrm{~mm}$, as fish larger than this in the fall are likely immature. All sampling was performed during the fall of 2007 (California: mid-August, ORWA: September, WCVI: October-November, CEBC: OctoberNovember,SEAK:October-November, SEBS:AugustSeptember, NEBS: August-September). Sampling was carried out in the fall because the stock composition of fall samples tends to better represent the region-of-capture (Tucker et al. 2011, 2012). Sampling in the fall also allows juveniles more time to move offshore (where they are available to surface trawls) and allows salmon more time to become equilibrated with oceanic baselines and lose freshwater isotopic signatures. Though they represent various freshwater life-history strategies, all juvenile Chinook salmon in this study entered the ocean sometime in the spring or summer of 2007 (Trudel et al. 2007). All programs used similar surface trawls towed behind large research or fishing vessels to collect the salmon; therefore, differences in sampling gear among regions are not expected to significantly bias our results. Once salmon were brought aboard the research vessel, they were euthanized, identified, measured, weighed and frozen for subsequent analysis.

Zooplankton samples were collected concurrently with salmon to use as an isotopic baseline in all regions but CA and ORWA. Though juvenile Chinook salmon do not typically feed directly on zooplankton prey, these organisms integrate the isotopic variability that occurs in phytoplankton, and serve as an effective baseline proxy for higher trophic levels 


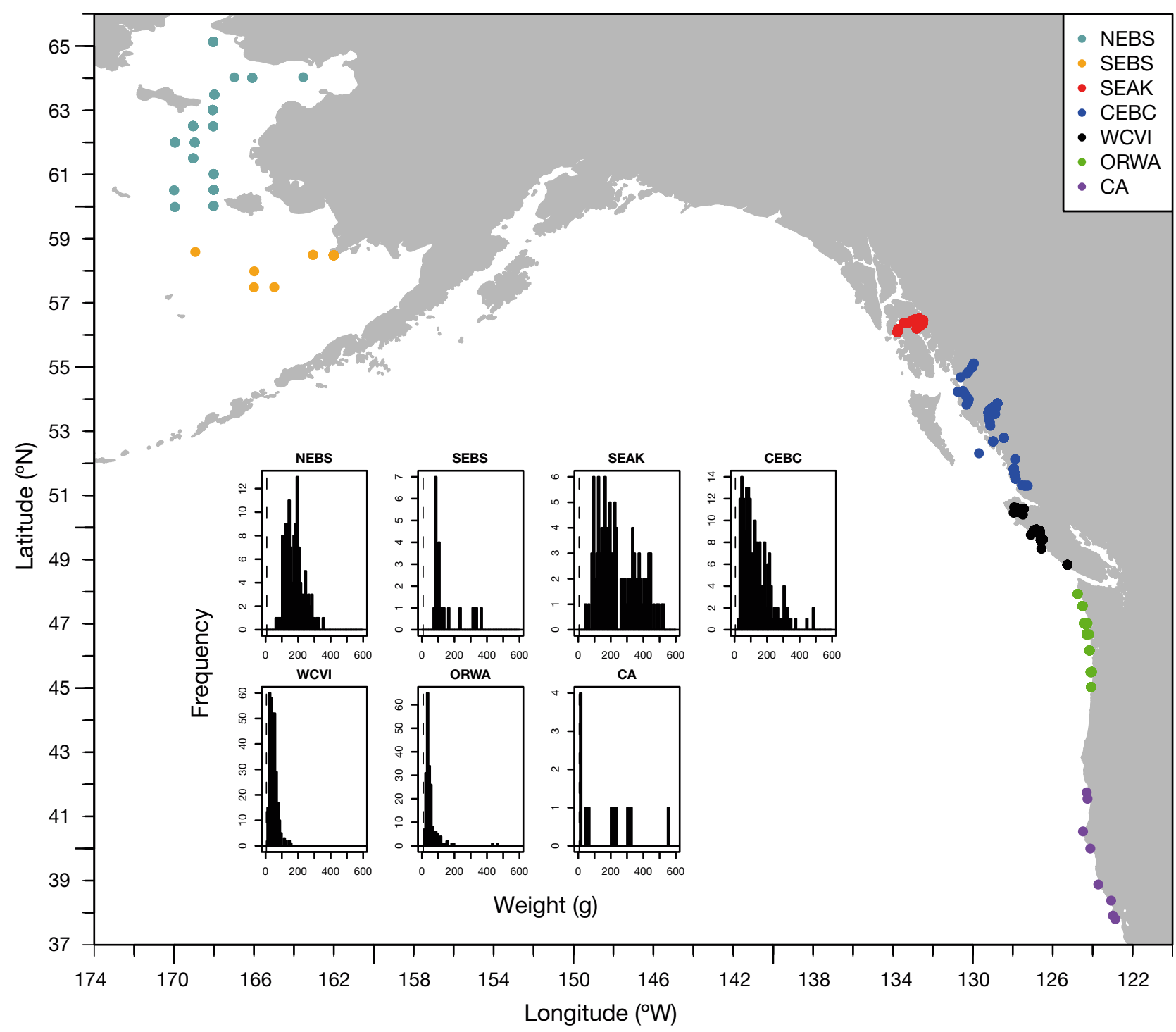

Fig. 1. Catch locations of juvenile Chinook salmon in the fall of 2007. Regional abbreviations: California (CA); Oregon and Washington (ORWA); west coast of Vancouver Island in British Columbia (WCVI); central British Columbia (CEBC); southeast Alaska (SEAK); southeastern Bering Sea (SEBS); northeastern Bering Sea (NEBS). Histograms of weight by region are also shown; dotted line in each histogram: average regional ocean entry size

(e.g. Miller et al. 2010). In WCVI, CEBC, and SEAK, these samples were taken by vertical bongo tows (236 $\mu \mathrm{m}$ black mesh), to $150 \mathrm{~m}$ or within $10 \mathrm{~m}$ of the ocean floor. Juvenile Chinook salmon do not typically forage at these depths, but many zooplankton undergo diel vertical migrations that bring them into the range of the salmon at their highest feeding intensity periods of dawn and dusk (Benkwitt et al. 2009). Samples were size-fractionated and the smallest size fraction ( 0.25 to $1.7 \mathrm{~mm}$ ) was used, due to the greater sampling coverage of this size fraction (El-Sabaawi et al. 2013). Zooplankton samples in SEBS and NEBS were sampled similarly (but using $335 \mu \mathrm{m}$ mesh), and then filtered to same size fraction as other regions (Coyle et al. 2011). A total of 124 size-fractionated zooplankton samples were analyzed.

Stomach contents of juvenile Chinook salmon were analyzed following Brodeur et al. (2007). Briefly, stomach contents were preserved in formalin, examined under a dissecting microscope and identified to the lowest possible taxonomic level. Prey items were grouped into 17 larger categories (taxonomic groupings) for statistical analyses. The categories used were: unidentifiable fish, northern anchovy Engraulis mordax, Pacific sandlance Ammodytes hexapte- 
rus, Pacific herring Clupea pallasii, capelin smelt Mallotus villossus, unidentified smelt (Osmeridae), walleye pollock Gadus chalcogrammus, sculpin (Cottidae), rockfish Sebastes spp., poacher (Agonidae), unidentified flatfish (Pleuronectidae), euphausiid, decapod, amphipod, cephalopod, insect, and other. Stomach contents from CA, ORWA, SEBS and NEBS were assessed using \% composition by weight at an individual level. In these regions, prey items were weighed after blotting dry. The data from these regions were then pooled by tow to prevent individual tows with large catches overwhelming any particular region and to facilitate comparison with WCVI, CEBC and SEAK, where stomach contents were assessed using \% composition by volume, and pooled by tow. Stomach content data was derived from 1046 juvenile Chinook salmon, with regional sample sizes ranging from 14 for CA to 332 for WCVI (see Fig. 2).

A random subset of 949 juvenile Chinook salmon were analyzed for stable isotopes of $\delta^{13} \mathrm{C}$ and $\delta^{15} \mathrm{~N}$. Regional sample size ranged from 13 juveniles in CA to 306 in WCVI (see Table S1 in the Supplement at www.int-res.com/articles/suppl/m537p247_supp.pdf). A piece of dorsal muscle tissue was taken from each juvenile salmon and freeze-dried. Zooplankton samples were also freeze-dried. Samples were ground to a fine powder and packed into tin capsules. A Thermo Delta IV Isotope Ratio Mass Spectrometer (at the University of Victoria) was used for the determination of stable isotope values. Atmospheric nitrogen was used as the standard for $\delta^{15} \mathrm{~N}$ and Vienna Peedee Belemnite was used as the standard for $\delta^{13} \mathrm{C}$. Stable isotope values are expressed in the delta notation:

$$
\delta^{15} \mathrm{~N}\left(\text { or } \delta^{13} \mathrm{C}\right)=\left(R_{\text {sample }} / R_{\text {standard }}-1\right) \times 1000
$$

where $R$ is ${ }^{15} \mathrm{~N}:{ }^{14} \mathrm{~N}$ or ${ }^{13} \mathrm{C}:{ }^{12} \mathrm{C}$.

We did not lipid-normalize the juvenile Chinook salmon samples or zooplankton baselines due to the possibility of taxonomic differences in the effects of lipids on the $\delta^{13} \mathrm{C}$ values of samples (Syväranta \& Rautio 2010, Fagan et al. 2011). However, results were qualitatively similar when using mathematical lipid-corrections derived for both zooplankton and fish (not shown).

\section{Statistical analysis}

Juvenile Chinook salmon stomach contents

We calculated trophic level (TL) from stomach contents data using the equation in Mearns et al. (1981):

$$
\mathrm{TL}_{\mathrm{sc}}=1+\sum_{\mathrm{n}=1}^{s}\left(K_{n} \times I_{n}\right)
$$

where $\mathrm{TL}_{\mathrm{sc}}$ is the TL calculated from stomach contents, $s$ is the number of prey categories, $K_{n}$ is the TL assignment of prey item $n$, and $I_{n}$ is the proportion of diet comprised of prey item $n$. As the TL of many prey species is difficult to quantify due to significant spatial and temporal variation in diet (Brodeur \& Pearcy 1992), we simply assumed that the fish and cephalopod portion of the diet was at TL 3, while all other prey items in the diet were at TL 2 . The assumption that zooplankton are TL 2 was made for both stable isotope and stomach content data, introducing the same bias and allowing the 2 methods to be compared within a region.

We also used stomach contents to determine whether there was evidence for ontogenetic shifts in the diet of the juvenile salmon. We tested whether there was a relationship between logit-transformed $\%$ of fish prey in the diet as a function of mass using linear regression. These analyses were performed for SEAK, CEBC, WCVI and ORWA. For SEAK, CEBC, and WCVI, these analyses were based on tow averages for both mass and fish prey, while for ORWA we analyzed both the individual and station-level data.

We used Levins' (1968) measure of niche breadth $(B)$ to quantify the difference in resource use breadth between regions using stomach content data:

$$
B=\frac{1}{\sum p_{j}^{2}}
$$

where $p_{j}$ is the fraction of the diet that is of food category $j$.

Regional differences in diet were explored using a multidimensional ordination plot (non-metric multidimensional scaling, NMDS) and were tested for statistical differences with an analysis of similarities (ANOSIM) test, which is a multivariate analog to analysis of variance (ANOVA). Both the ordination and ANOSIM statistical test were based on the Bray-Curtis matrix of station- or haul-averaged diet compositions. These analyses were concerned with comparing regions, and did not take size into consideration. Unidentified fish were reallocated to identified fish categories in proportion to the known identifiable fish at the sampling station. If all fish prey were unidentifiable at the station, we used the regionallyaveraged proportion of known fish prey. Finally, we used similarity percentage analysis (SIMPER) to identify the prey categories that contributed the most to the differences among the statistically different regions $(p<0.05)$ found through the ANOSIM analysis. 


\section{Zooplankton stable isotopes}

To test for regional differences in the $\delta^{13} \mathrm{C}$ and $\delta^{15} \mathrm{~N}$ of zooplankton, we used a Kruskal-Wallis test, since variances among groups were unequal (Levene's test: $\mathrm{p}<0.05)$. Differences among regions were assessed using the 'kruskalmc' post hoc test in the R package 'pgirmess' (Giraudoux 2014).

\section{Juvenile Chinook salmon stable isotopes}

Variation in baseline $\delta^{15} \mathrm{~N}$ can obscure differences in an organism's $\delta^{15} \mathrm{~N}$ independent of the variability caused by diet (Cabana \& Rasmussen 1996), so we converted all juvenile Chinook salmon $\delta^{15} \mathrm{~N}$ values to trophic positions. There appears to be an inverse relationship between $\delta^{15} \mathrm{~N}$ in the diet of an organism and the trophic enrichment that an organism experiences (Caut et al. 2009). This relationship indicates that by assuming a constant trophic enrichment, there can be an underestimation in the TL of higher TL organisms (Hussey et al. 2014). Thus, we used this scaled approach to calculate TL, rearranged from Hussey et al. (2014):

$$
\mathrm{TL}_{\text {Hussey }}=\log \left(\frac{\delta^{15} \mathrm{~N}_{\text {lim }}-\delta^{15} \mathrm{~N}_{\text {base }}}{\delta^{15} \mathrm{~N}_{\text {lim }}-\delta^{15} \mathrm{~N}_{\text {fish }}}\right)^{1 / k}+\mathrm{TL}_{\text {base }}
$$

where $\mathrm{TL}_{\text {Hussey }}$ is the trophic level of juvenile Chinook salmon, $\delta^{15} \mathrm{~N}_{\text {lim }}$ (the limit of $\delta^{15} \mathrm{~N}$ values as TL increases) and $k$ are fitted parameters from the metaanalysis by Hussey et al. (2014), $\delta^{15} \mathrm{~N}_{\text {base }}$ is the baseline $\delta^{15} \mathrm{~N}$ value from zooplankton samples, $\delta^{15} \mathrm{~N}_{\text {fish }}$ is the $\delta^{15} \mathrm{~N}$ of the juvenile Chinook salmon sampled, and $\mathrm{TL}_{\text {base }}$ is the trophic level of the baseline organism chosen. We assumed that the zooplankton samples from all regions were TL 2. To compare standard TL estimates to this scaled approach, we also calculated TL following Cabana \& Rasmussen (1996), with a constant trophic enrichment of 3.4\% (Post 2002).

To observe how isotopes changed with size in each region, we plotted the $\delta^{13} \mathrm{C}, \delta^{15} \mathrm{~N}$ and TL values of juvenile Chinook salmon in each region as a function of mass. We used a formulation of the logistic model to model the processes of isotopic turnover and ontogenetic niche shifts in each region:

$$
\delta_{x i}=\frac{\alpha}{1+\mathrm{e}^{\frac{\beta-W_{i}}{\theta}}}
$$

where $\delta_{x i}$ are the individual isotopic values of either $\delta^{15} \mathrm{~N}$ or TL, $\alpha$ is the asymptotic value reached at equilibrium, $\beta$ is the inflection point, $W_{\mathrm{i}}$ is the mass of each fish at capture and $\theta$ is a scaling parameter.
This formulation of the logistic model does not fit negative values well, so to fit $\delta^{13} \mathrm{C}$ models, we first multiplied all $\delta^{13} \mathrm{C}$ values by -1 , then used

$$
\delta_{x i}=\frac{\alpha}{1-\mathrm{e}^{\frac{\beta-W_{i}}{\theta}}}
$$

We were interested in whether there were regional differences in the isotopic values at equilibrium, so we used a non-linear mixed effects (NLME) modeling approach (Pinheiro \& Bates 2000). We compared a model with no random effects (i.e. all parameters were the same in all regions) to models where $\alpha$ or $\beta$ were the random effects (i.e. these parameters varied by region). We also compared these models to a model where all 3 parameters were random effects (i.e. all varied by region). We used Akaike's information criterion (AIC) to determine which model was most supported by the data. Due to the lack of small fish in SEBS and NEBS, for the $\delta^{15} \mathrm{~N}$ and $\delta^{13} \mathrm{C}$ models we simply assumed that there was a linear relationship between isotopes and size, with a slope of 0 , and intercept equal to the mean. For TL models, we also had to exclude CA and ORWA, as these regions lacked the zooplankton baseline data needed to calculate TL. We used the R package 'nlme' to fit all models (Pinheiro et al. 2014).

Finally, recent approaches examining variation in isotopes at population-level scales have emphasized the power of simultaneously looking at variation in $\delta^{15} \mathrm{~N}-\delta^{13} \mathrm{C}$ bivariate space (Layman et al. 2007, Jackson et al. 2011). However, because ocean entry size, time since ocean entry, and growth rates vary among regions (Trudel et al. 2007), the amount of tissue that has been turned over in each region is different. To minimize differences caused by these factors, we retained juvenile Chinook salmon that were predicted to be within $95 \%$ of their asymptotic weight. To do so, we set $\delta_{x i}$ to be $95 \%$ of the regional asymptotic value, and solved Eq. (6) using the parameters from our best fit NLME model for $\delta^{13} \mathrm{C}$ (since $\delta^{13} \mathrm{C}$ had a slower turnover time than $\delta^{15} N_{\text {; }}$ see Fig. 4), retaining all juvenile Chinook salmon larger than this value (hereafter equilibrated juvenile Chinook salmon). We also retained all SEBS and NEBS juvenile Chinook salmon for this analysis, as the lack of a size effect on the isotopic ratios suggest that they were equilibrated with their prey in these regions. Overall, there were 386 juvenile Chinook salmon that fitted our operational definition for equilibrium, with sample size of equilibrated juvenile Chinook salmon ranging from 7 in CA to 144 in SEAK (Table S1). Due to low sample sizes of equilibrated 
juvenile Chinook salmon in $\mathrm{CA}$, this region was not included in subsequent analyses.

In bivariate $\delta^{13} \mathrm{C}-\delta^{15} \mathrm{~N}$ space, we tested for differences in isotopic niche position among regions using the residual permutation procedures outlined in Turner et al. (2010). This method is based on Euclidean distance measures of each individual's position in bivariate $\delta^{13} \mathrm{C}-\delta^{15} \mathrm{~N}$ space (Turner et al. 2010). We ran the procedure for 1000 iterations. We calculated $\delta^{15} \mathrm{~N}$ and $\delta^{13} \mathrm{C}$ ranges for both zooplankton and equilibrated juvenile Chinook salmon following Layman et al. (2007). To test for differences in the isotopic niche breadth among regions, we used stable isotope Bayesian ellipses in R (SIBER; Jackson et al. 2011). This method constructs the parameters of ellipses from each region using Markov Chain Monte Carlo simulations, and provides an estimate of the average size of the isotopic niche that is relatively insensitive to sample size and outliers (Jackson et al. 2011). Baseline variability can also contribute to niche differences between regions (e.g. Hoeinghaus \& Zeug 2008), so we also used SIBER to explore the variability present in the zooplankton baseline of different regions. All analyses were performed in the statistical language R (R Development Core Team 2013).

\section{Environmental drivers of variability}

Finally, we tested the effects of SST on the average $\delta^{13} \mathrm{C}$ values of zooplankton and juvenile Chinook salmon. Monthly average SST data were obtained in a $1^{\circ}$ latitude $\times 1^{\circ}$ longitude grid resolution from the NOAA OI.v2 SST data (Reynolds et al. 2002). These data are a combination of satellite and in situ measurements, and were obtained from the NOAA National Centers for Environmental Prediction (ftp:// ftp.emc.ncep.noaa.gov/cmb/). In each region, over the latitudes where juvenile Chinook salmon were caught, we averaged the SST in the $1 \times 1^{\circ}$ block nearest to the coast over the period from May to October. In SEBS and NEBS, juvenile Chinook salmon were distributed over a broader area, therefore we extended our analysis to the maximal longitude where they were caught. The relationships between SST and zooplankton $\delta^{13} \mathrm{C}$ and equilibrated juvenile Chinook salmon $\delta^{13} \mathrm{C}$ were assessed using separate linear regressions.

\section{RESULTS}

\section{Juvenile Chinook salmon stomach contents}

Stomach content analysis showed regional differences in the feeding of juvenile Chinook salmon (Fig. 2). All pairs of regions were significantly different from each other (ANOSIM; $\mathrm{p}<0.05)$ with the exception of SEBS \& NEBS, and CEBC \& SEAK. Juvenile salmon in ORWA, SEAK and NEBS were predominately piscivorous, with different fish prey in each region. Northern anchovy and unidentified smelt were highly consumed in ORWA, Pacific herring and Pacific sandlance in SEAK, and capelin smelt and Pacific sandlance were the dominant fish prey in NEBS (Fig. 2; SIMPER). Pacific herring was the primary fish prey in CEBC and WCVI, and capelin smelt was the common fish prey in SEBS along with walleye pollock. Juvenile rockfish and euphausiids were the top prey in CA, Pacific sandlance was consumed in each region north of WCVI, and amphipods were important in all regions except ORWA and SEAK (SIMPER). There were a large amount of unidentifiable fish in most regions, comprising 40 to $60 \%$ of total weight or volume in CA, ORWA, and SEAK (Fig. 2).

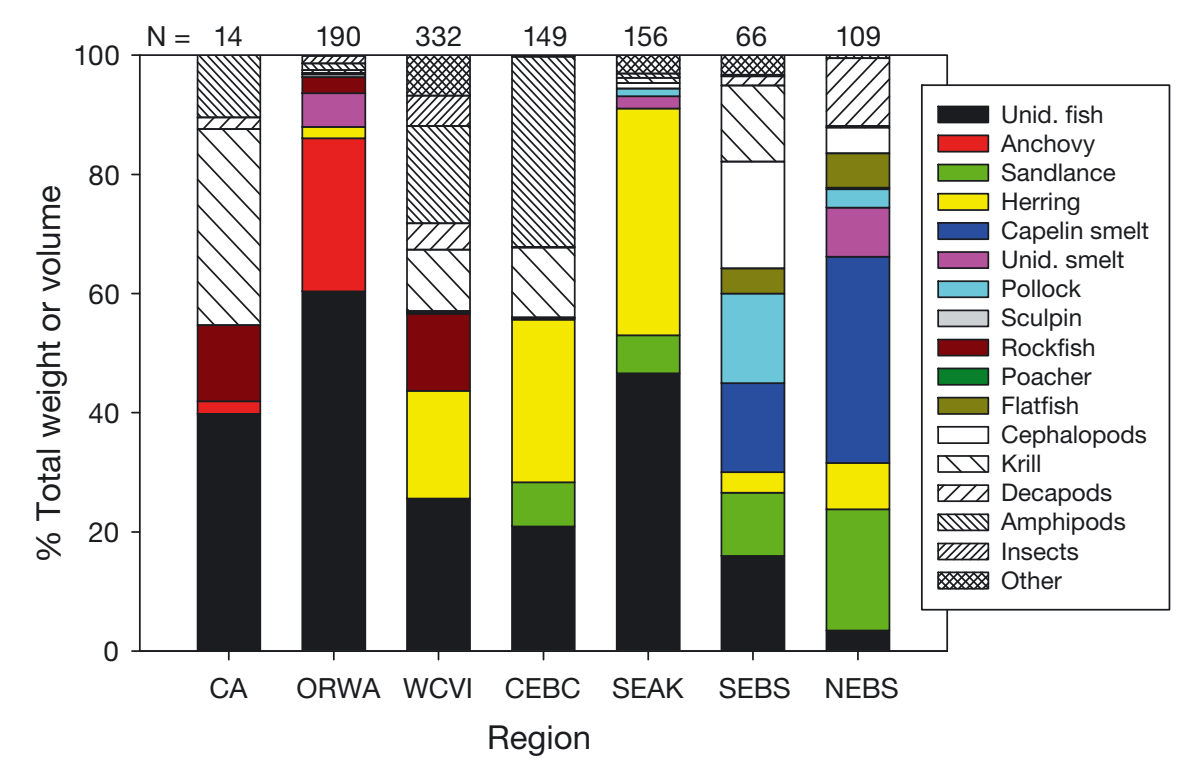

Fig. 2. Regional composition of stomach contents of juvenile Chinook salmon for the grouped prey categories. The number of stomachs examined $(\mathrm{N})$ is given at the top of each bar. See Fig. 1 legend for region abbreviations 
Stomach content data indicated that Levins' niche breadth was largest in SEBS and WCVI (7.4 and 6.2 respectively). Niche breadth was intermediate in NEBS, CEBC and CA, with values of 5.1, 4.2 and 3.4, and was lowest in SEAK (2.7) and ORWA (2.3).

The NMDS showed that the diet compositions of SEBS and NEBS were distinct from the other regions, especially along axis 1, and encompassed a broad ordination space relative to the other regions, whereas diets in ORWA, SEAK, and most of WCVI showed much less variability and were closely grouped (Fig. 3). These patterns match closely to those shown by Levins' niche breadth. In the NMDS, anchovy and rockfish loaded positively onto axis 1, while capelin loaded negatively on this axis. On axis 2, amphipods and pollock loaded positively, while sandlance and herring loaded negatively (Fig. 3). We found no evidence for ontogenetic niche shifts with size in any region from stomach content data, irrespective if the data were pooled by station or examined on an individual basis $(p>0.05$; Fig. S1 in the Supplement at www.int-res.com/articles/suppl/ m537p247_supp.pdf).

\section{Zooplankton stable isotopes}

Zooplankton $\delta^{15} \mathrm{~N}$ was significantly different among regions (Kruskal-Wallis $\chi^{2}=63.1$, $\mathrm{df}=4, \mathrm{p}<0.0001$ ).

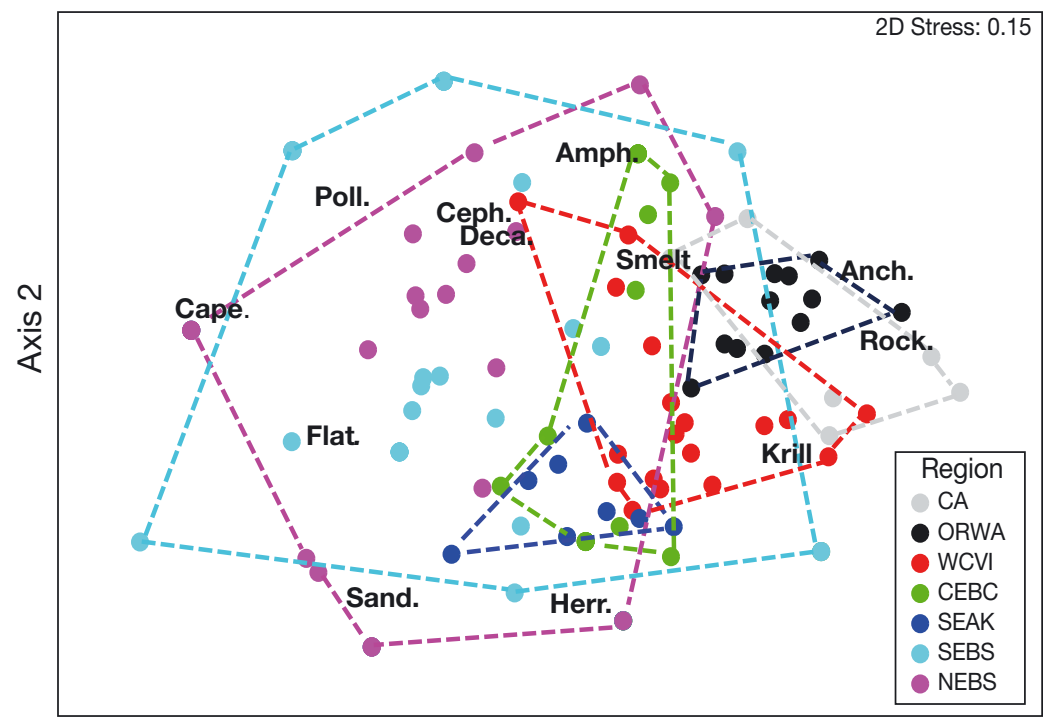

Axis 1

Fig. 3. Non-metric multidimensional scaling ordination plot showing the relationship of diet composition color-coded by region (see Fig. 1 legend for region abbreviations). Each point represents the overall diet of juvenile Chinook salmon at a given station. The dashed lines encompass the variability within each region. Prey loadings are indicated by text. See Fig. 2 for full taxon names
The WCVI $\delta^{15} \mathrm{~N}$ values were significantly lower compared to all regions except for CEBC (Table S2). Zooplankton $\delta^{13} \mathrm{C}$ was also significantly different among regions (Kruskal-Wallis $\chi^{2}=68.3$, df $=4, \mathrm{p}<0.0001$ ). WCVI, CEBC and SEAK were generally more enriched than SEBS or NEBS (Table S2). Finally, the C:N ratios of zooplankton were significantly different between regions (Kruskal-Wallis $\chi^{2}=87.4$, df $=4, \mathrm{p}<$ 0.0001 ) with values above 7 in SEBS and NEBS, and lowest in CEBC with a value near 4 (Table S2). The comparisons between SEAK and WCVI, and SEBS and NEBS, were the only non-significant differences.

\section{Juvenile Chinook salmon stable isotopes}

The average mass at capture of juvenile Chinook

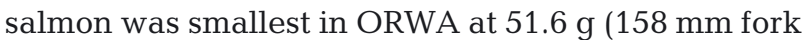
length) and largest in SEAK at $251.7 \mathrm{~g}$ (260 mm fork length) (Fig. 1). The plots of isotopes against mass show that in most areas, the juvenile salmon rapidly shift their diet and turn over tissue until they reach a plateau at approximately $85 \mathrm{~g}$ (roughly $200 \mathrm{~mm}$ ) (Fig. 4; see Fig. S2 for plots by fork length). The isotopic value at which this plateau is reached appears to be different among regions; the AIC values of the NLME models confirm this, in that best model fits for each variable included $\alpha$ as a random effect (i.e. varies among regions) (Table 1 ). For $\delta^{13} \mathrm{C}$, the best model included only $\alpha$ as a random effect, with $\beta$ and $\theta$ as fixed effects. $\alpha$ values were highest in WCVI at $-15.9 \%$, and lowest in SEAK at $-17.8 \%$ o (Fig. 4). For $\delta^{15} \mathrm{~N}$ and $\mathrm{TL}_{\text {Hussey' }}$ the best models included $\alpha, \beta$ and $\theta$ as random effects. For the best $\delta^{15} \mathrm{~N}$ model, $\alpha$ values were highest in WCVI at $15.1 \%$ and lowest in CA at $12.8 \%$ (Fig. 4). For TL Hussey, WCVI had the highest $\alpha$ value of 4.1, and CEBC had the lowest of 3.3. For SEBS and NEBS, the mean $\delta^{15} \mathrm{~N}$ values were more enriched and the mean $\delta^{13} \mathrm{C}$ values were more depleted than the predicted $\alpha$ values from all other regions (Table 2). TL estimates from stomach contents and stable isotopes were similar for NEBS and SEBS (Fig. 5). The predicted TL from SIA was lower than that predicted from stomach content analysis in CEBC and SEAK, with isotopes predicting a TL approximately 0.3 to 0.5 TLs below that of the stom- 

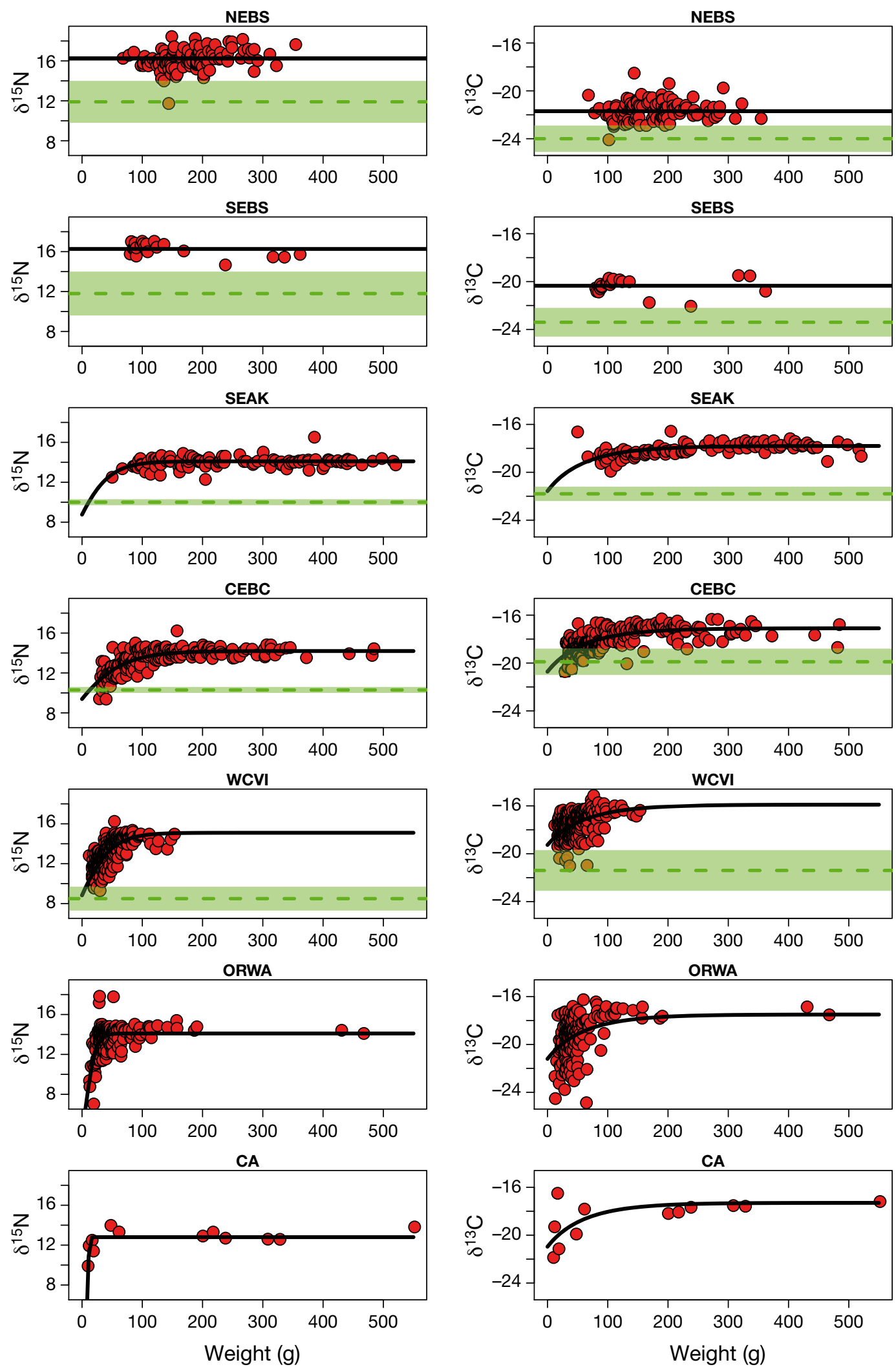

Fig. 4. Regional relationships between the stable isotopes of nitrogen and carbon $\left(\delta^{15} \mathrm{~N}, \delta^{13} \mathrm{C}\right)$ and size of juvenile Chinook salmon. See Fig. 1 legend for region abbreviations. Solid lines: the best non-linear mixed effects (NLME) model fits for each region (except for NEBS and SEBS, where averages are displayed due to the lack of a size effect); dashed lines: zooplankton baseline values in the regions where they were sampled; shaded area: $\pm 1 \mathrm{SD}$ 
Table 1. Results of fitting various non-linear mixed effect models on the relationships between $\delta^{13} \mathrm{C}, \delta^{15} \mathrm{~N}$ (stable isotopes of carbon and nitrogen), $\mathrm{TL}_{\mathrm{Hussey}}$ (trophic level of juvenile Chinook salmon based on Hussey et al. 2014) and size. NLL: negative log-likelihood; AIC: Akaike's information criterion; $\alpha$ : asymptotic value reached at equilibrium; $\beta$ : inflection point; $\theta$ : scaling parameter. The best model for each variable is shown in bold

\begin{tabular}{|lrrrr|}
\hline Random effects & NLL & AIC & $\Delta$ AIC & df \\
\hline$\delta^{15} \mathrm{~N}$ & & & & \\
None & -1152.7 & 2313.4 & 229.1 & 807 \\
$\alpha$ & -1083.0 & 2176.0 & 91.7 & 5 \\
$\beta$ & -1077.4 & 2164.8 & 80.5 & 5 \\
$\boldsymbol{\alpha}, \boldsymbol{\beta}, \boldsymbol{\theta}$ & $\mathbf{- 1 0 3 2 . 2}$ & $\mathbf{2 0 8 4 . 3}$ & $\mathbf{0}$ & $\mathbf{1 0}$ \\
$\delta^{13} \mathrm{C}$ & & & & \\
None & -1324.9 & 2657.9 & 360.3 & 807 \\
$\boldsymbol{\alpha}$ & $\mathbf{- 1 1 4 3 . 8}$ & $\mathbf{2 2 9 7 . 6}$ & $\mathbf{0 . 0}$ & $\mathbf{5}$ \\
$\beta$ & -1169.3 & 2348.6 & 51.0 & 5 \\
$\alpha, \beta, \theta$ & -1140.5 & 2301.1 & 3.5 & 10 \\
TL & & & & \\
$\alpha$ & -77.5 & 165.1 & 0.5 & 3 \\
$\beta$ & -222.6 & 455.2 & 290.6 & 3 \\
$\boldsymbol{\alpha}, \boldsymbol{\beta}, \boldsymbol{\theta}$ & $-\mathbf{7 2 . 3}$ & $\mathbf{1 6 4 . 6}$ & $\mathbf{0}$ & $\mathbf{6}$ \\
\hline
\end{tabular}

ach contents. The pattern was the opposite in WCVI, where stable isotopes predicted a TL approximately 0.5 TL above stomach contents (Fig. 5).
Table 2. Parameter values of best fit non-linear mixed effect models for the logistic change in isotopic values of juvenile Chinook salmon. $\alpha$ : asymptotic value reached at equilibrium; $\beta$ : inflection point; $\theta$ : scaling parameter. $\mathrm{TL}_{\mathrm{Hussey}}$ : trophic level of juvenile Chinook salmon based on Hussey et al. (2014). See Fig. 1 legend for region abbreviations

\begin{tabular}{|c|c|c|c|c|}
\hline Isotope & Region & $\alpha$ & $\beta$ & $\theta$ \\
\hline \multirow[t]{7}{*}{$\delta^{15} \mathrm{~N}$} & NEBS & $16.3^{\mathrm{a}}$ & & \\
\hline & SEBS & $16.3^{\mathrm{a}}$ & & \\
\hline & SEAK & 14.1 & -13.8 & 27.9 \\
\hline & CEBC & 14.2 & -28.4 & 42.5 \\
\hline & WCVI & 15.1 & -9.4 & 27.4 \\
\hline & ORWA & 14.1 & 6.8 & 7.9 \\
\hline & $\mathrm{CA}$ & 12.8 & 8.9 & 1.2 \\
\hline \multirow[t]{7}{*}{$\delta^{13} \mathrm{C}$} & NEBS & $-21.7^{\mathrm{a}}$ & & \\
\hline & SEBS & $-20.4^{\mathrm{a}}$ & & \\
\hline & SEAK & -17.8 & -121.4 & 69.6 \\
\hline & CEBC & -17.1 & -121.4 & 69.6 \\
\hline & WCVI & -15.9 & -121.4 & 69.6 \\
\hline & ORWA & -17.5 & -121.4 & 69.6 \\
\hline & $\mathrm{CA}$ & -17.3 & -121.4 & 69.6 \\
\hline \multirow[t]{5}{*}{$\mathrm{TL}_{\text {Hussey }}$} & NEBS & $3.9^{\mathrm{a}}$ & & \\
\hline & SEBS & $3.8^{\mathrm{a}}$ & & \\
\hline & SEAK & 3.4 & 1.3 & 36.3 \\
\hline & CEBC & 3.3 & 1.3 & 37.3 \\
\hline & WCVI & 4.1 & 1.3 & 26.7 \\
\hline
\end{tabular}

\section{Equilibrated juvenile Chinook salmon stable isotopes and baseline variability}

Using the residual permutation procedure in Turner et al. (2010), we determined that the mean centroid location of each region differed from zero $(p=0.001)$. This suggests that each region occupied a unique area in isotopic niche space (Fig. 6c). Comparing the relative ellipses for each region using SIBER showed that the largest niche area was in NEBS $(p<0.01)$ (Fig. 6d). SEBS also had a significantly larger niche area than SEAK $(\mathrm{p}<0.01)$, but niche area did not differ significantly among the other regions.

We also used SIBER to explore the variability present in the baseline of different regions because
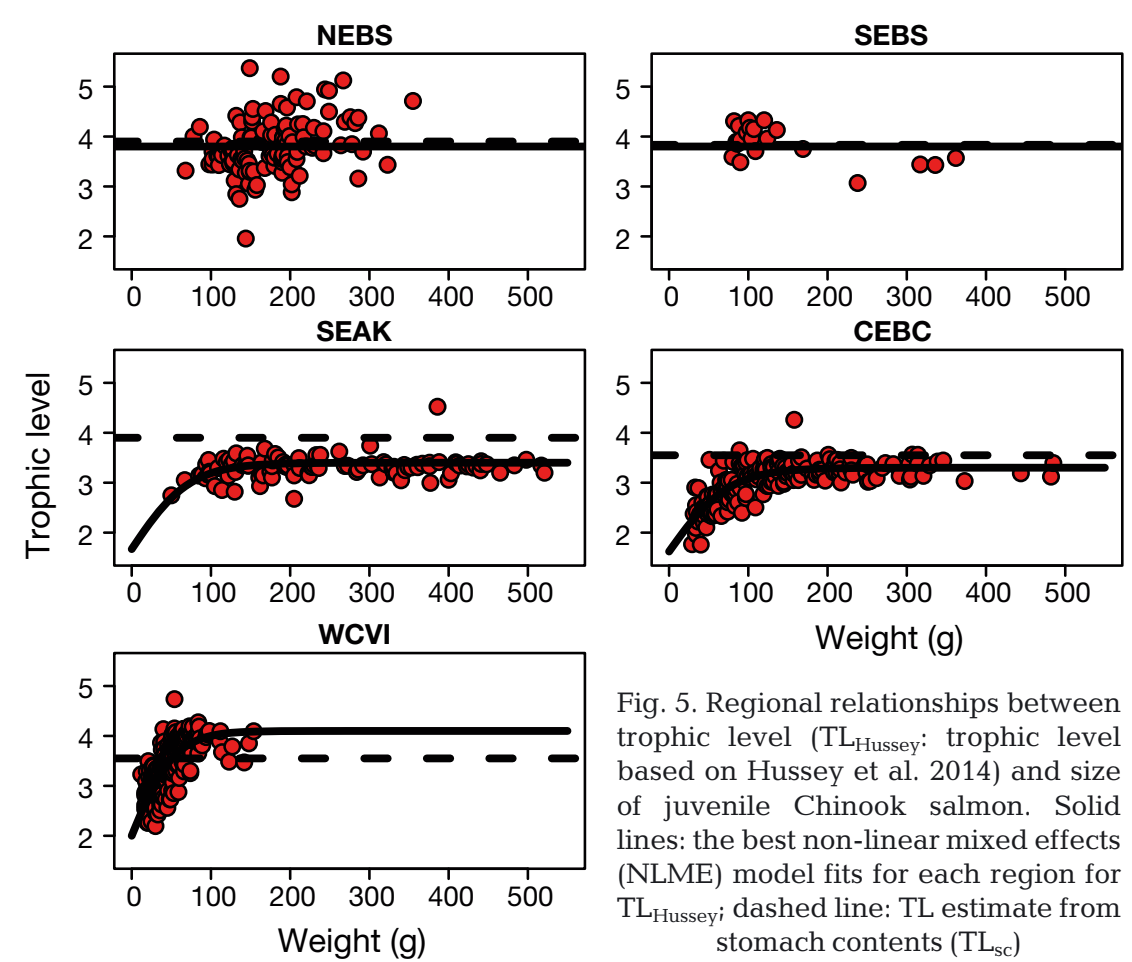

Fig. 5. Regional relationships between trophic level ( $\mathrm{TL}_{\mathrm{Hussey}}$ : trophic level based on Hussey et al. 2014) and size of juvenile Chinook salmon. Solid lines: the best non-linear mixed effects (NLME) model fits for each region for $\mathrm{TL}_{\mathrm{Hussey}}$ dashed line: TL estimate from stomach contents $\left(\mathrm{TL}_{\mathrm{sc}}\right)$ 

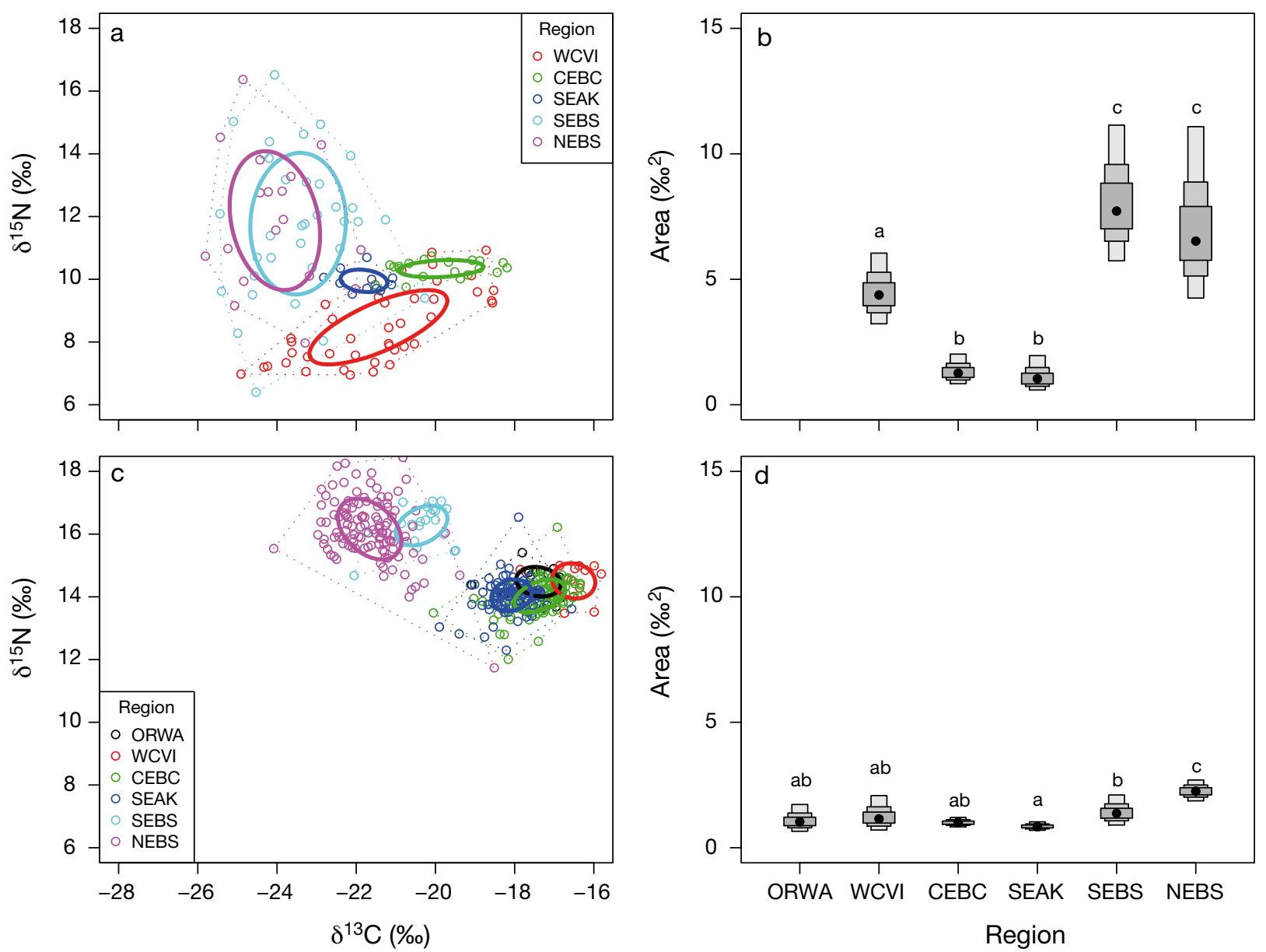

Fig. 6. Regional isotopic niche spaces of zooplankton and equilibrated juvenile Chinook salmon. See Fig. 1 legend for region abbreviations. (a) and (b) are plots for zooplankton baseline values, while (c) and (d) are equilibrated juvenile Chinook salmon. $(\mathrm{a}, \mathrm{c})$ Bivariate plots of the isotopic niches. Ellipses: standard ellipse area (bivariate equivalent to standard deviation); dashed lines: convex hulls (Layman et al. 2007). (b,d) Credible intervals of isotopic niche widths from stable isotope Bayesian ellipses in R (SIBER; Jackson et al. 2011). Black dots are the mode, with intervals going from 50, 75 and $95 \%$ credible intervals from dark to light grey boxes. Different letters refer to significant differences in the isotopic niche width among regions

baseline variability can confound large-scale comparisons. We found that the variability seen in juvenile Chinook salmon was largely similar to the regional differences in variability in zooplankton (Fig. 6a,b). Equilibrated juvenile Chinook salmon were generally enriched in $\delta^{15} \mathrm{~N}$ relative to zooplankton by approximately 3 to $5 \%$ o (Fig. 6a,c). The $\delta^{13} \mathrm{C}$ values of equilibrated juvenile Chinook salmon were generally enriched by over $2 \%$ relative to zooplankton $\delta^{13} \mathrm{C}$ values (Fig. 6a,c). Similar to juvenile salmon, zooplankton in NEBS and SEBS had the significantly largest niche areas, CEBC and SEAK had the smallest niche areas, and WCVI was intermediate (Fig. 6b). Interestingly, the niche variation present in zooplankton was dampened in the juvenile Chinook salmon, with each region showing much greater variation in niche areas at the zoo- plankton rather than the salmon level (Fig. 6a,c). The results from the $\delta^{15} \mathrm{~N}$ and $\delta^{13} \mathrm{C}$ ranges showed largely the same patterns as those shown by the SIBER plots (Table S3).

\section{Environmental drivers of variability}

Average SST varied from lows of 6.7 and $6.6^{\circ} \mathrm{C}$ in NEBS and SEBS respectively, to a high of $13.8^{\circ} \mathrm{C}$ in ORWA. The relationship between average SST and zooplankton $\delta^{13} \mathrm{C}$ was significant $(\mathrm{p}=0.005)$ and positive (Fig. 7). Similarly, the relationship between average SST and equilibrated juvenile Chinook salmon $\delta^{13} \mathrm{C}$ was significant $(\mathrm{p}=0.004)$ and positive, though the relationship appears to be largely driven by the very low values in SEBS and NEBS (Fig. 7). 


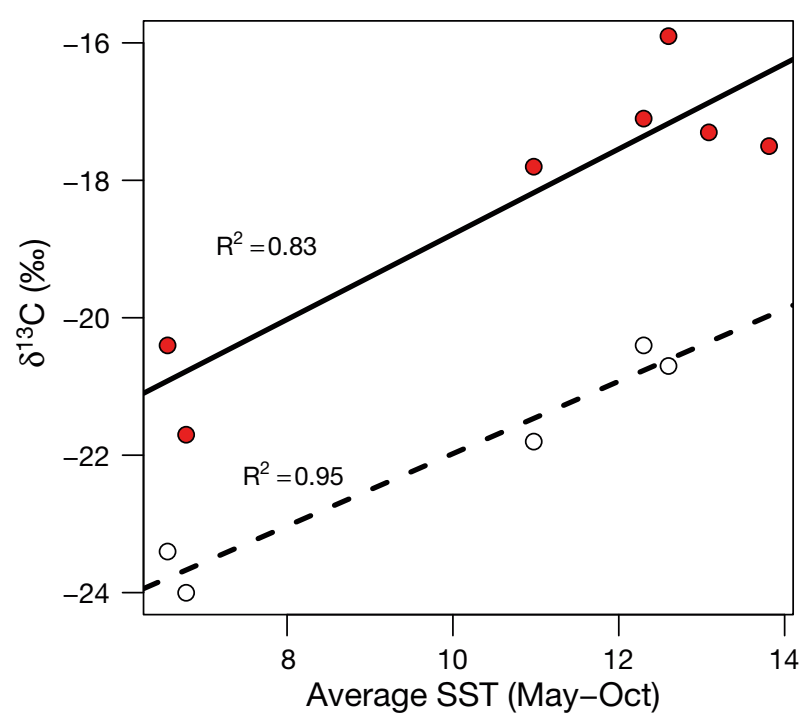

Fig. 7. Relationships between average May-October sea surface temperatures (SST) and the $\delta^{13} \mathrm{C}$ of zooplankton (open circles) and equilibrated juvenile Chinook salmon (filled red circles). Lines indicate the best fit linear relationship between variables

\section{DISCUSSION}

Our analyses showed large regional differences in the feeding ecology of juvenile Chinook salmon along the west coast of North America. The asymptotic $\delta^{13} \mathrm{C}$ and $\delta^{15} \mathrm{~N}$ values of juvenile Chinook salmon varied by region, and these trends may coincide with regional variability in oceanography. Stomach contents and SIA indicated somewhat dissimilar results, especially with regards to ontogeny and TL estimates. While previous studies have assessed the stomach contents of juvenile Chinook salmon on a similar scale (Brodeur et al. 2007), this is the first study to combine multiple approaches to assess the ontogeny of feeding ecology on a continental scale.

The stomach content data for 2007 presented here matches the same general pattern as that of Brodeur et al. (2007). That is, juvenile Chinook salmon are generally piscivorous in most areas, but in coastal British Columbia and CA, other prey can make up a significant portion of their diet. In 2007, the non-fish prey that made up the remainder of the diet in CA were euphausiids, which contrasts with the period of 2000 to 2002, when juvenile Chinook salmon in this area fed mainly on cephalopods (Brodeur et al. 2007). For the eastern Bering Sea salmon we found similar patterns to Farley et al. (2009), who reported that fish were important components of the diets of juvenile Chinook salmon from 2003 to 2006. Interestingly, while Farley et al. (2009) found that the juvenile salmon from SEBS were generally more piscivorous than those from NEBS, in 2007 we found the opposite pattern. The food web structure of the Bering Sea appears to be related to SST, and 2003 to 2005 was a warm period in the Bering Sea, while 2007 was a cool year (Coyle et al. 2011). It is thus possible that the shift in ocean conditions in 2007 resulted in higher piscivory in NEBS, possibly due to shift in the distribution of age-0 walleye pollock, which were a primary prey item of juvenile salmon in warm years, but shifted their distribution offshore and deeper in cool years (Parker-Stetter et al. 2013).

The British Columbia coastal areas also showed an interesting pattern with regards to stomach contents, with salmon from both WCVI and CEBC having nearly $50 \%$ of their diet made up of non-fish prey, and covering a smaller ordination space relative to those from SEBS and NEBS. Interpretation of these regional differences in stomach contents is difficult without complimentary sampling of the prey field (Brodeur et al. 2011). Furthermore, this finding may be partially due to salmon size in WCVI, where relatively small size-at-capture meant that these salmon may have been captured before the majority of them had completed their shift to piscivory. Altogether, the diet differences that we observed are probably very conservative since we had to group prey into broader categories (e.g. euphausiids, amphipods, decapods, and some of the fish groupings) due to advanced digestion in many cases, but many of these prey taxa are likely to be different between regions as they have limited geographical ranges. The advanced digestion of many prey items also calls into question the assertion that stomach contents provide a greater taxonomic resolution than stable isotopes, and echoes Baker et al. (2014) who noted that unidentifiable and inseparable digested material in stomach contents can introduce significant and unquantifiable error. Interestingly, we did not detect evidence for ontogenetic shifts in diet using stomach content data for the regions that we tested in this study. Given that previous stomach content studies with larger size ranges and sample sizes have noted strong evidence for ontogeny in ORWA (Brodeur 1991, Daly et al. 2009) and WCVI (E. Hertz et al. unpubl. data), the lack of a trend seen in our stomach content analyses is probably due to the relatively low sample sizes and smaller size ranges in this study, or the fact that we had to average stomach contents by station rather than by individual.

The relationships between size and $\delta^{13} \mathrm{C}, \delta^{15} \mathrm{~N}$, and $\mathrm{TL}_{\text {Hussey }}$ show similar asymptotic trends in most regions, and the same processes likely underlie these 
trends. Chinook salmon stocks generally vary in their ocean-entry date, size and growth (Quinn 2005, Trudel et al. 2007). This means that throughout the sampling period, each individual will vary in the amount of time available for it to reach equilibrium with the marine environment, as well as have a different amount of tissue that needs to become equilibrated (Hesslein et al. 1993). These effects are likely to be larger in individuals from ORWA since this area has a larger size-at-entry, later entry date, and a wider range of size variation than other regions (Trudel et al. 2007). Overlain on this variability is the ontogenetic niche shift that occurs in juvenile Chinook salmon when they reach the marine environment. That is, as the juveniles grow, they generally become more piscivorous until they reach a regionspecific plateau in the contribution of fish to the diet (Brodeur 1991, Daly et al. 2009, E. Hertz et al. unpubl. data). Furthermore, individual salmon also vary in growth rate, which can be a primary driver of tissue turnover in fast-growing juvenile fish (Buchheister \& Latour 2010). Hence, this combination of date of ocean entry, amount of tissue to turn over, growth rate, and ontogeny likely determines where in this general curve each juvenile Chinook salmon would be found. On a population level, some regions with an earlier migration time (relative to the survey) may have already moved beyond this shifting isotope phase (e.g. SEAK, SEBS and NEBS). Conversely, the populations with a relatively late migration time, or large variability in release date (in the case of hatchery juvenile Chinook salmon), may not have yet reached their plateau (e.g. ORWA).

The best models for $\delta^{13} \mathrm{C}, \delta^{15} \mathrm{~N}$, and TL Hussey all included $\alpha$ as a random effect, which indicates that there were significant differences in the regional asymptotic stable isotope values for juvenile Chinook salmon, even without including SEBS and NEBS (the 2 regions with the most unique isotopic values). We found a significant relationship between SST and the $\delta^{13} \mathrm{C}$ value for equilibrated juvenile Chinook salmon, as well as between SST and the average $\delta^{13} \mathrm{C}$ value for zooplankton. High latitude, lower-SST systems tend to have high concentrations of dissolved $\mathrm{CO}_{2}$ due to the greater solubility of $\mathrm{CO}_{2}$ in cooler water as well as the vertical mixing of the water column (Newsome et al. 2010). These conditions can lead to low $\delta^{13} \mathrm{C}$ values, as the fractionation associated with photosynthetic $\mathrm{CO}_{2}$ uptake becomes greater with higher $\mathrm{CO}_{2}$ concentrations (Laws et al. 1995, Newsome et al. 2010).

The regional differences in $\delta^{13} \mathrm{C}$ could also reflect differences in factors that affect phytoplankton growth rate, with higher $\delta^{13} \mathrm{C}$ associated with greater primary productivity (Laws et al. 1995, Schell 2000, Miller et al. 2008). This general link between primary productivity and $\delta^{13} \mathrm{C}$ is also supported by our data, as primary productivity along the coast of North America is highest off WCVI (Ware \& Thomson 2005), and juvenile Chinook salmon from this area had the highest asymptotic $\delta^{13} \mathrm{C}$ values. We were unable to further directly assess this hypothesis, as chlorophyll a $(\mathrm{chl} a)$, the only metric of primary productivity that was available across our study range, is derived from satellite data (e.g. SeaWiFS). This is problematic for a number of reasons. Firstly, the majority of fish in WCVI, CEBC and SEAK were caught in inlets and straits, where there are no direct measures of chl $a$, and where satellite-derived data are unreliable. Second is the problem of cloud cover, which can be extensive in the regions of study. Finally, there is the problem of the unknown and possibly significant time lag between chl a values and the corresponding isotopic values of zooplankton and salmon. Therefore, while productivity could also be driving some of the regional variation in $\delta^{13} \mathrm{C}$, we were unable to assess its effect in this study.

Equilibrated juvenile Chinook salmon were enriched in $\delta^{13} \mathrm{C}$ relative to zooplankton $\delta^{13} \mathrm{C}$ by values generally more than $2 \%$. This is greater than the typically-assumed enrichment of 0 to $1 \%$ (Post 2002), but is within the range of literature values ( -3 to $3 \%$; McCutchan et al. 2003). The fact that lipids were not removed from samples may explain some of this discrepancy, since lipids are depleted in ${ }^{13} \mathrm{C}$ (McConnaughey \& McRoy 1979), and zooplankton had higher lipids than juvenile Chinook salmon.

Stomach contents and stable isotopes gave different estimates for a number of parameters. In 2 out of the 5 regions where we had estimates of TL from stomach contents and stable isotopes (CEBC and SEAK), SIA provided an estimate for TL that was approximately 0.3 to $0.5 \mathrm{TLs}$ below the TL estimate from stomach contents. These results were qualitatively similar when we used traditional TL estimates (Cabana \& Rasmussen 1996, Fig. S3 in the Supplement at www.int-res.com/articles/suppl/m537p247_ supp.pdf). The difference in TL estimates from stomach contents and SIA may be a function of the different periods over which these metrics integrate. Stomach contents are a snapshot of diet that generally represents material consumed over the last $24 \mathrm{~h}$ (Polunin \& Pinnegar 2002) while stable isotopes reflect a period of weeks to months (Fry 2006). As juvenile Chinook salmon generally experience ontogenetic shifts in their diet in the marine environment 
(Brodeur 1991, Daly et al. 2009), the differences that we found between these approaches may be because the juvenile Chinook salmon had recently shifted their diet to fish, but due to the time lag associated with stable isotopes, the SIA still indicated a diet higher in non-fish prey.

Another explanation for the underestimated TL of juvenile Chinook salmon from SIA in some regions could come from the assumption of zooplankton being at a TL of 2. Zooplankton are rarely strictly herbivorous, and there can be significant omnivory within the zooplankton TL (Kling et al. 1992, ElSabaawi et al. 2013). This means that the TL of the regional baselines may be appreciably higher than 2 , and the estimates from stomach contents and stable isotopes may converge.

A final explanation for this disagreement between TL estimates from stomach content and stable isotope approaches concerns the differential digestibility of prey items (Polunin \& Pinnegar 2002). Because fish prey are generally larger than other prey items in the stomachs of juvenile Chinook salmon, they may be expected to digest slower than other prey items, and thus end up over-represented in the stomach content data. Supporting this possibility, He \& Wurtsbaugh (1993) found that in brown trout Salmo trutta, evacuation rates decreased with increasing prey size. Similarly, Tanasichuk et al. (1991) found that Pacific hake Merluccius productus digested euphausiid prey faster than fish prey. Finally, the WCVI TL estimate from stable isotopes was approximately 0.5 TL above the TL estimate from stomach contents, possibly due to the lack of a clear asymptote in this region, or because the resolution of the zooplankton baseline was insufficient. Altogether, these results again indicate the sensitivity of TL estimates to differences in discrimination values, and highlight the need to consider multiple approaches when calculating TLs at a large scale.

Because of the regional differences in $\delta^{13} \mathrm{C}$ and $\delta^{15} \mathrm{~N}$ at the base of the food web, it is not surprising that equilibrated juvenile Chinook salmon from each region occupied a unique area in bivariate isotopic niche space. We found that there were no significant differences among isotopic niche breadths from ORWA, WCVI, CEBC and SEBS. Because we limited this comparison to only the large fish in each region, this finding is not particularly surprising. However, NEBS showed the significantly largest niche area, while SEAK had a niche area significantly smaller than SEBS and NEBS. For NEBS, the large niche area was likely due to a combination of the large variability in prey isotopic niche, plus the large variability in stomach contents in this region. In contrast, SEAK had significantly less baseline variability than other regions, combined with less variability in stomach contents, leading to a small isotopic niche.

One limitation of our study is that we were unable to control for stock-of-origin, as different stocks of Chinook salmon may have different diets (Schabetsberger et al. 2003). In most regions, the juvenile salmon we sampled were from a variety of stocks, with various stock-specific life-histories and migration patterns (e.g. Tucker et al. 2011, 2012). For instance, WCVI juvenile Chinook salmon were probably primarily from WCVI stocks, but Columbia River and other Washington stocks can represent over $10 \%$ of catches in some years (Trudel et al. 2009, Tucker et al. 2011, 2012). Similarly, juvenile Chinook salmon caught in SEBS in 2007 were likely a mixture of Yukon River Chinook and southern Bering Sea stocks (Murphy et al. 2009). Considering the previous studies on migration patterns, however, each region was probably primarily represented by fish that originated from that region. Future studies should look into patterns of stock-specific resource utilization across large spatial scales.

Overall, our results indicate that regardless of the approach we used, there was substantial variation in the feeding ecology of juvenile Chinook salmon from California to the eastern Bering Sea. Considering that the factors underlying the recent widespread declines of Chinook salmon survival from Alaska to California are not well understood (Schindler et al. 2013, Riddell et al. 2013), determining how differences in feeding ecology could affect the survival rates of Chinook salmon in each region is important to explore further.

Acknowledgements. The authors thank the numerous colleagues who were instrumental in collecting and processing the salmon in this study. We also thank the captains and crews of the CCGS 'W. E. Ricker', FV 'Frosti', and FV 'Sea Storm'. We thank Skip McKinnell for collating the sea surface temperature data. Marisa Litz, Brian Starzomski, James Robinson, and 3 anonymous reviewers provided helpful comments on an earlier draft of the manuscript. We thank NSERC, Fisheries and Oceans Canada, the US National Marine Fisheries Service and Bonneville Power Administration for funding.

\section{LITERATURE CITED}

Baker R, Buckland A, Sheaves M (2014) Fish gut content analysis: robust measures of diet composition. Fish Fish 15:170-177

Benkwitt CE, Brodeur RD, Hurst TP, Daly EA (2009) Diel feeding chronology, gastric evacuation, and daily food consumption of juvenile Chinook salmon in Oregon 
coastal waters. Trans Am Fish Soc 138:111-120

Brodeur RD (1991) Ontogenetic variations in the type and size of prey consumed by juvenile coho, Oncorhynchus kisutch, and Chinook, O. tshawytscha, salmon. Environ Biol Fishes 30:303-315

Brodeur RD, Pearcy WG (1992) Effects of environmental variability on trophic interactions and food web structure in a pelagic upwelling ecosystem. Mar Ecol Prog Ser 84: 101-119

Brodeur RD, Daly EA, Sturdevant MV, Miller TW and others (2007) Regional comparisons of juvenile salmon feeding in coastal marine waters off the west coast of North America. Am Fish Soc Symp 57:183-204

Brodeur RD, Daly EA, Benkwitt CE, Morgan CA, Emmett RL (2011) Catching the prey: sampling juvenile fish and invertebrate prey fields of juvenile coho and Chinook salmon during their early marine residence. Fish Res 108:65-73

Brown ZW, van Dijken GL, Arrigo KR (2011) A reassessment of primary production and environmental change in the Bering Sea. J Geophys Res 116:C08014, doi:10.1029/ 2010JC006766

> Buchheister A, Latour RJ (2010) Turnover and fractionation of carbon and nitrogen stable isotopes in tissues of a migratory coastal predator, summer flounder (Paralichthys dentatus). Can J Fish Aquat Sci 67:445-461

Cabana G, Rasmussen JB (1996) Comparison of aquatic food chains using nitrogen isotopes. Proc Natl Acad Sci USA 93:10844-10847

Caut S, Angulo E, Courchamp F (2009) Variation in discrimination factors $\left(\Delta^{15} \mathrm{~N}\right.$ and $\left.\Delta^{13} \mathrm{C}\right)$ : the effect of diet isotopic values and applications for diet reconstruction. J Appl Ecol 46:443-453

Claiborne AM, Fisher JP, Hayes SA, Emmett RL (2011) Size at release, size-selective mortality, and age of maturity of Willamette River hatchery yearling Chinook salmon. Trans Am Fish Soc 140:1135-1144

> Coyle KO, Eisner LB, Mueter FJ, Pinchuk AI and others (2011) Climate change in the southeastern Bering Sea: impacts on pollock stocks and implications for the oscillating control hypothesis. Fish Oceanogr 20:139-156

> Daly EA, Brodeur RD, Weitkamp LA (2009) Ontogenetic shifts in diets of juvenile and subadult coho and Chinook salmon in coastal marine waters: Important for marine survival? Trans Am Fish Soc 138:1420-1438

Davis ND, Myers KW, Ishida Y (1998) Caloric values of highseas salmon prey organisms and simulated salmon ocean growth and prey consumption. North Pac Anadromous Fish Comm Bull 1:146-162

Davis ND, Volkov AV, Efimkin AY, Kuznetsova NA, Armstrong JL, Sakai O (2009) Review of BASIS salmon food habits studies. North Pac Anadromous Fish Comm Bull 5: 197-208

de Roos AM, Persson L (2013) Population and community ecology of ontogenetic development. Princeton University Press, Princeton, NJ

Duffy EJ, Beauchamp DA (2011) Rapid growth in the early marine period improves the marine survival of Chinook salmon (Oncorhynchus tshawytscha) in Puget Sound, Washington. Can J Fish Aquat Sci 68:232-240

> Duffy EJ, Beauchamp DA, Sweeting RM, Beamish RJ, Brennan JS (2010) Ontogenetic diet shifts of juvenile Chinook salmon in nearshore and offshore habitats of Puget Sound. Trans Am Fish Soc 139:803-823

Eisner LB, Napp JM, Mier KL, Pinchuk AI, Andrews AG
(2014) Climate-mediated changes in zooplankton community structure for the eastern Bering Sea. Deep-Sea Res II 109:157-171

El-Sabaawi R, Trudel M, Mazumder A (2013) Zooplankton stable isotopes as integrators of bottom-up variability in coastal margins: a case study from the Strait of Georgia and adjacent coastal regions. Prog Oceanogr 115:76-89

Fagan KA, Koops MA, Arts MT, Power M (2011) Assessing the utility of $\mathrm{C}: \mathrm{N}$ ratios for predicting lipid content in fishes. Can J Fish Aquat Sci 68:374-385

Farley EV Jr, Murphy JM, Eisner L, Middleton A and others (2005) Eastern Bering Sea (BASIS) coastal research (August-October 2004) on juvenile salmon. North Pac Anadromous Fish Comm Doc No. 914, Alaska Fisheries Science Center, Juneau, AK

Farley EV Jr, Murphy JM, Moss J, Feldmann A, Eisner L (2009) Marine ecology of western Alaska juvenile salmon. Am Fish Soc Symp 70:307-330

Fry B (2006) Stable isotope ecology. Springer Science+Business Media, New York, NY

Giraudoux P (2014) Package 'pgirmess': data analysis in ecology. http://CRAN.R-project.org/web/packages/pgirmess/ pgirmess.pdf

He E, Wurtsbaugh WA (1993) An empirical model of gastric evacuation rates for fish and an analysis of digestion in piscivorous brown trout. Trans Am Fish Soc 122:717-730

Hesslein RH, Hallard KA, Ramlal P (1993) Replacement of sulfur, carbon, and nitrogen in tissue of growing broad whitefish (Coregonus nasus) in response to a change in diet traced by $\delta^{34} \mathrm{~S}, \delta^{13} \mathrm{C}$, and $\delta^{15} \mathrm{~N}$. Can J Fish Aquat Sci 50:2071-2076

Hickey BM (1979) The California Current system-hypotheses and facts. Prog Oceanogr 8:191-279

Hickey BM, Banas NS (2008) Why is the northern end of the California Current so productive? Oceanography 21: 90-107

> Hoeinghaus DJ, Zeug SC (2008) Can stable isotope ratios provide for community-wide measures of trophic structure? Ecology 89:2353-2357

> Hunt GL Jr, Stabeno P, Walters G, Sinclair E, Brodeur RD, Napp JM, Bond NA (2002) Climate change and control of the southeastern Bering Sea pelagic ecosystem. DeepSea Res II 49:5821-5853

Hussey NE, MacNeil MA, McMeans BC, Olin JA and others (2014) Rescaling the trophic structure of marine food webs. Ecol Lett 17:239-250

Jackson AL, Inger R, Parnell AC, Bearhop S (2011) Comparing isotopic niche widths among and within communities: SIBER-Stable Isotope Bayesian Ellipses in R. J Anim Ecol 80:595-602

Keeley ER, Grant JW (2001) Prey size of salmonid fishes in streams, lakes, and oceans. Can J Fish Aquat Sci 58: 1122-1132

Kling GW, Fry B, O'Brien WJ (1992) Stable isotopes and planktonic trophic structure in Arctic lakes. Ecology 73: 561-566

Larkin PA (1996) Concepts and issues in marine ecosystem management. Rev Fish Biol Fish 6:139-164

Laws EA, Popp BN, Bidigare RR, Kennicutt MC, Macko SA (1995) Dependence of phytoplankton carbon isotopic composition on growth rate and $\left[\mathrm{CO}_{2}\right]_{\mathrm{aq}}$ : theoretical considerations and experimental results. Geochim Cosmochim Acta 59:1131-1138

Layman CA, Arrington DA, Montaña CG, Post DM (2007) Can stable isotope ratios provide for community-wide 
measures of trophic structure? Ecology 88:42-48

Lee RL, Hagen W, Kattner G (2006) Lipid storage in marine zooplankton. Mar Ecol Prog Ser 307:273-306

Levins R (1968) Evolution in changing environments: some theoretical explorations. Princeton University Press, Princeton, NJ

McCann KS, Rasmussen JB, Umbanhowar J (2005) The dynamics of spatially coupled food webs. Ecol Lett 8: 513-523

> McConnaughey T, McRoy CP (1979) Food-web structure and the fractionation of carbon isotopes in the Bering Sea. Mar Biol 53:257-262

> McCutchan JH, Lewis WM, Kendall C, McGrath CC (2003) Variation in trophic shift for stable isotope ratios of carbon, nitrogen, and sulfur. Oikos 102:378-390

McMahon KW, Hamady LL, Thorrold SR (2013) Ocean ecogeochemistry: a review. Oceanogr Mar Biol Annu Rev 51:327-374

Mearns AJ, Young DR, Olson RJ, Schafer HA (1981) Trophic structure and the cesium-potassium ratio in pelagic ecosystems. CCOFI Rep 22:99-110

Miller TW, Brodeur RD, Rau G (2008) Carbon stable isotopes reveal relative contribution of shelf-slope production to the northern California Current pelagic community. Limnol Oceanogr 53:1493-1503

Miller TW, Brodeur RD, Rau G, Omori K (2010) Prey dominance shapes trophic structure of the northern California Current pelagic food web: evidence from stable isotopes and diet analysis. Mar Ecol Prog Ser 420:15-26

Murphy JM, Templin WD, Farley EV Jr, Seeb JE (2009) Stock-structured distribution of western Alaska and Yukon juvenile Chinook salmon (Oncorhynchus tshawytscha) from United States BASIS surveys, 2002-2007. North Pac Anadromous Fish Comm Bull 5:51-59

Newsome SD, Clementz MT, Koch PL (2010) Using stable isotope biogeochemistry to study marine mammal ecology. Mar Mamm Sci 26:509-572

> Nunn AD, Tewson LH, Cowx IG (2012) The foraging ecology of larval and juvenile fishes. Rev Fish Biol Fish 22: $377-408$

Orsi JA, Harding JA, Pool SS, Brodeur RD and others (2007) Epipelagic fish assemblages associated with juvenile Pacific salmon in neritic waters of the California Current and the Alaska Current. Am Fish Soc Symp 57:105-155

Parker-Stetter SL, Horne JK, Farley EV, Barbee DH, Andrews AG, Eisner LB, Nomura JM (2013) Summer distributions of forage fish in the eastern Bering Sea. DeepSea Res II 94:211-230

Pazzia I, Trudel M, Ridgway M, Rasmussen JB (2002) Influence of food web structure on the growth and bioenergetics of lake trout (Salvelinus namaycush). Can J Fish Aquat Sci 59:1593-1605

Perry RI, Thompson PA, Mackas DL, Harrison PJ, Yelland D (1999) Stable carbon isotopes as pelagic food web tracers in adjacent shelf and slope regions off British Columbia, Canada. Can J Fish Aquat Sci 56:2477-2486

Pikitch EK, Santora EA, Babcock A, Bakun A and others (2004) Ecosystem-based fishery management. Science 305:346-347

Pinheiro JC, Bates DM (2000) Mixed-effects models in S and S-PLUS. Springer, New York, NY

Pinheiro JC, Bates DM, DebRoy S, Sarkar D, R Core Team (2014) nlme: linear and nonlinear mixed effects models. R package version 3.1-118. http://CRAN.R-project.org/ package $=$ nlme
Polunin NVC, Pinnegar JK (2002) Trophic ecology and the structure of marine food webs. In: Hart PJ, Reynolds JD (eds) Handbook of fish and fisheries. Blackwell Science, Oxford, p 301-320

$>$ Post DM (2002) Using stable isotopes to estimate trophic position: models, methods, and assumptions. Ecology 83: 703-718

Quinn TP (2005) The behaviour and ecology of Pacific salmon and trout. University of British Columbia Press, Vancouver

R Development Core Team (2013) R: a language and environment for statistical computing. R Foundation for Statistical Computing, Vienna. www.R-project.org/

Reynolds RW, Rayner NA, Smith TM, Stokes DC, Wang W (2002) An improved in situ and satellite SST analysis for climate. J Clim 15:1609-1625

Riddell B, Bradford M, Carmichael R, Hankin D, Peterman R, Wertherimer A (2013) Assessment of status and factors for decline of southern BC Chinook salmon: independent panel's report. ESSA Technologies, Vancouver

Rudolf VHW, Lafferty KD (2011) Stage structure alters how complexity affects stability of ecological networks. Ecol Lett 14:75-79

Rudolf VHW, Rasmussen NL (2013) Ontogenetic functional diversity: size structure of a keystone predator drives functioning of a complex ecosystem. Ecology 94: 1046-1056

Schabetsberger R, Morgan CA, Brodeur RD, Potts CL, Peterson WT, Emmett RL (2003) Prey selectivity and diel feeding chronology of juvenile Chinook (Oncorhynchus tshawytscha) and coho (O. kisutch) salmon in the Columbia River plume. Fish Oceanogr 12:523-540

> Scharf FS, Juanes F, Rountree RA (2000) Predator size-prey size relationships of marine fish predators: interspecific variation and effects of ontogeny and body size on trophic-niche breadth. Mar Ecol Prog Ser 208:229-248

> Schell DM (2000) Declining carrying capacity in the Bering Sea: isotopic evidence from whale baleen. Limnol Oceanogr 45:459-462

Schindler D, Krueger C, Bisson P, Bradford M and others (2013) Arctic-Yukon-Kuskokwim Chinook salmon research action plan: evidence of decline of Chinook salmon populations and recommendations for future research. AYK Sustainable Salmon Initiative, Anchorage, AK

Syväranta J, Rautio M (2010) Zooplankton, lipids and stable isotopes: importance of seasonal, latitudinal, and taxonomic differences. Can J Fish Aquat Sci 67:1721-1729

Tanasichuk RW, Ware DM, Shaw W, McFarlane GA (1991) Variations in diet, daily ration, and feeding periodicity of Pacific hake (Merluccius productus) and spiny dogfish (Squalus acanthias) off the lower west coast of Vancouver Island. Can J Fish Aquat Sci 48:2118-2128

Trudel M, Thiess ME, Bucher C, Farley EV Jr and others (2007) Regional variation in the marine growth and energy accumulation of juvenile Chinook salmon and coho salmon along the west coast of North America. Am Fish Soc Symp 57:205-232

Trudel M, Fisher J, Orsi JA, Morris JFT and others (2009) Distribution and migration of juvenile Chinook salmon derived from coded wire tag recoveries along the continental shelf of western North America. Trans Am Fish Soc 138:1369-1391

Tucker S, Trudel M, Welch DW, Candy JR and others (2011) Life history and seasonal stock-specific ocean migration 
of juvenile Chinook salmon. Trans Am Fish Soc 140: 1101-1119

Tucker S, Trudel M, Welch DW, Candy JR and others (2012) Annual coastal migration of juvenile Chinook salmon: static stock-specific patterns in a highly dynamic ocean. Mar Ecol Prog Ser 449:245-262

Turner TF, Collyer ML, Krabbenhoft TJ (2010) A general hypothesis-testing framework for stable isotope ratios in ecological studies. Ecology 91:2227-2233

van Leeuwen A, Huss M, Gårdmark A, de Roos AM (2014) Ontogenetic specialism in predators with multiple niche shifts prevents predator population recovery and establishment. Ecology 95:2409-2422

Ware DM, McFarlane GA (1989) Fisheries production domains in the northeast Pacific. Publ Spec Can Sci Halieut Aquat 108:359-379

Ware DM, Thomson RE (2005) Bottom-up ecosystem trophic dynamics determine fish production in the northeast

Editorial responsibility: Stylianos Somarakis, Heraklion, Greece
Pacific. Science 308:1280-1284

Weiss R (1974) Carbon dioxide in water and seawater: the solubility of a non-ideal gas. Mar Chem 2:203-215

Weitkamp LA, Sturdevant MA (2008) Food habits and marine survival of juvenile Chinook and coho salmon from marine waters of Southeast Alaska. Fish Oceanogr 17: 380-395

Werner EE, Gilliam JF (1984) The ontogenetic niche and species interactions in size-structured populations. Annu Rev Ecol Syst 15:393-425

Wollrab S, de Roos AM, Diehl S (2013) Ontogenetic diet shifts promote predator-mediated coexistence. Ecology 94:2886-2897

Woodson LE, Wells BK, Weber PK, MacFarlane RB, Whitman GE, Johnson RC (2013) Size, growth, and origindependent mortality of juvenile Chinook salmon Oncorhynchus tshawytscha during early ocean residence. Mar Ecol Prog Ser 487:163-175

Submitted: February 16, 2015; Accepted: July 28, 2015 Proofs received from author(s): October 1, 2015 